University of Nebraska - Lincoln

DigitalCommons@University of Nebraska - Lincoln

2008

\title{
The Army Dietetic Mentorship Program: Making the Most Out of Mentoring
}

\author{
M.A. Worley \\ U.S. Army Medical Department Center and School, Fort Sam Houston \\ M.B. Salgueiro \\ U.S. Army Medical Department Center and School, Fort Sam Houston \\ D.R. Hernandez \\ U.S. Army Medical Department Center and School, Fort Sam Houston \\ C.J. Buck \\ U.S. Army Medical Department Center and School, Fort Sam Houston
}

Follow this and additional works at: https://digitalcommons.unl.edu/usarmyresearch

Part of the Operations Research, Systems Engineering and Industrial Engineering Commons

Worley, M.A.; Salgueiro, M.B.; Hernandez, D.R.; and Buck, C.J., "The Army Dietetic Mentorship Program: Making the Most Out of Mentoring" (2008). US Army Research. 66.

https://digitalcommons.unl.edu/usarmyresearch/66

This Article is brought to you for free and open access by the U.S. Department of Defense at DigitalCommons@University of Nebraska - Lincoln. It has been accepted for inclusion in US Army Research by an authorized administrator of DigitalCommons@University of Nebraska - Lincoln. 
Title: THE ARMY DIETETIC MENTORSHIP PROGRAM: MAKING THE MOST OUT OF MENTORING

Author(s): M. A. Worley, M. B. Salgueiro, D. R. Hernandez, C. J. Buck; U.S. Army Medical Department Center and School, Fort Sam Houston, TX

Learning Outcome: To describe the Army's Dietetic Mentorship Program and its effect on personnel and professional development of recent internship graduates.

Text: Mentoring is a passionate subject in academia, business, and the military. Benefits include: increased employee retention, improved productivity, and professional development. The Army's operational tempo makes it difficult for leaders to find time for mentoring. Educators in the U.S. Military Dietetic Internship Consortium received feedback indicating the need for dietitian mentorship, which led to a formal survey of program graduates to determine mentoring needs. Survey results suggested that new graduates did not always receive guidance on expectations, duty performance, military professionalism, and career planning. A oneyear "structured mentoring" initiative was developed. Mentors and mentees were matched based on a needs assessment, and mentors were provided information to discuss during monthly sessions. Program goals were to facilitate the transition from dietetic intern to staff member; provide continual military orientation; improve job satisfaction; develop technical and leadership skills; and introduce mentoring benefits. To evaluate effectiveness, an end of program survey was completed by each group using a five-point Likert-type scale to elicit responses to items related to program structure, mentoring relationship and benefits. Response rate was $88 \%$ and results indicate that the program structure and matching process worked well, and program goals were achieved. Unexpected mentee beneficial outcomes included completion of a research protocol, selection for promotion, advanced specialty certification, and enrollment into a MS program. Due to this success, senior leadership expanded the program to include all new fully-credentialed Army dietitians. This effective mentoring program is now a key to Army dietitians acclimating to their role as military officers and dietitians.

Funding Disclosure: None

Journal of the American Dietetic Association September 2008 (Vol. 108, Issue 9, Page A67)

This article is a U.S. government work, and is not subject to copyright in the United States. 